\title{
Cranioplasty and Craniofacial Reconstruction: A Review of Implant Material, Manufacturing Method and Infection Risk
}

\author{
Jeremy Kwarcinski ${ }^{1,+}$, Philip Boughton ${ }^{1,+}$, Andrew Ruys ${ }^{1}$, Alessandra Doolan ${ }^{2}$ \\ and James van Gelder ${ }^{3, *}$ \\ 1 Faculty of Engineering and IT, The University of Sydney, Sydney NSW 2006, Australia; \\ jeremy.kwarcinski@sydney.edu.au (J.K.); philip.boughton@sydney.edu.au (P.B.); \\ andrew.ruys@sydney.edu.au (A.R.) \\ 2 Sydney Medical School, The University of Sydney, Sydney NSW 2006, Australia; A.doolan@htaconsult.com \\ 3 Sydney Spine Institute, Sydney NSW 1805, Australia \\ * Correspondence: james.vangelder@gmail.com; Tel.: +61-2-9715-5007 \\ † Jeremy Kwarcinski and Philip Boughton contributed equally to this work.
}

Academic Editor: Daniel X.B. Chen

Received: 30 November 2016; Accepted: 6 March 2017; Published: 10 March 2017

\begin{abstract}
Background: Analysis of current literature highlights a wide variation in reported infection risk for different materials in cranial repair. The purpose of these composite materials are to mimic natural bone and assist in restoring function (structurally and aesthetically) to the human skull. This review aims to examine the meta-data in order to provide an amalgamated overview of potential trends between implant material, manufacturing method and infection risk, in order to provide a core reference point for future studies surrounding emerging biomedical materials in the fields of cranioplasty by providing base point for understanding the capabilities and limitations of current technologies. Methods: A search for articles was conducted, with the following criteria seen as fundamental in providing an accurate picture of the current landscape: publication in the last decade, provision of a numerical value for both number of implants and infection cases, patient sample of 10+, adult patients, and cranioplasty/cranial repair. Results: A total of 41 articles were seen to meet the author's inclusion criteria. Average infection rates per material ranged between $2.04 \%$ and $10.98 \%$. The results indicate that there is variation between materials in regards to total infection risk, however, depending on the materials compared, this value may be insignificant. Alternative risk factors associated with infection, including surgical time, revisions and previous infection, have a greater impact on infection potential than material variation. Comparison of fabrication methods did highlight a notable effect on average infection rate. Trends can be observed showing that materials with greater levels of surface interaction and active support of tissue ingrowth presented greater infection resistance. Such characteristics are due to the physical structures of the implants. Conclusions: It can be said that the manufacturing methods can influence biomedical materials to assist in minimizing implant infection risk.
\end{abstract}

Keywords: cranioplasty; craniofacial; bone; reconstruction; material; graft; infection

\section{Introduction}

Cranial and craniofacial implants vary significantly based on the cause of injury and the surrounding anatomical structures and functions. The properties of such implants are tied closely to the material(s) and method(s) used to construct them. Desired properties such as biocompatibility, bioactivity, toxicity, yield strength, flexural modulus, implantation complexity and infection risk are all 
defined by the choice of material and, as such, implant material consideration remains a key factor in cranial and craniofacial reconstruction [1-5].

Of these properties, infection remains a core concern in regards to implant failure and patient health $[1,6,7]$. Thus, it is fundamental than any implantable reconstruction solution aims to mitigate infection risk potential to the greatest possible extent. There are many contributing factors which can impact the potential infection risk for a patient. These include factors such as pre-existing infection and latency period between tissue removal and implant insertion $[1,7,8]$, number of previous operations and time between operations $[1,7,9]$ and surgical time $[6,10,11]$. The impact of implant material and manufacture method on infection rate is a source of controversy in literature, with data on infection and material varying widely between published studies [12].

The aim of this review was to provide an overview of implantable materials for cranioplasty and craniofacial reconstruction and to provide a comparison of available data in regards to reconstruction material and potential infection risk.

\section{Materials and Methods}

This review is based on publications found through the University of Sydney CrossSearch-ProQuest portal between January and April 2016. The inclusion criteria encompassed publications from 2005 onward with a cranioplasty/craniofacial implant focus, a total patient sample of 10 or greater, provision of a numerical value for total number of implants per material, as well as a numerical value for cases of infection per material. Points of examination included number of patients, materials utilized, fabrication method utilized (where applicable) and infection rate. Only first-time cranioplasty implants are considered in this study. The data from the studies was broken down based on material, leading to the following analysis groups:

- Autologous bone (craniotomy bone flap)

- Polymethylmethacrylate (PMMA)

Hand-formed
Prefabricated
Templated

- Titanium

$\bigcirc \quad$ Plate

- Mesh

- Hydroxyapatite (HA)

- $\quad$ Polyetheretherketone (PEEK)

- Polyethylene (PE)

- Calcium Phosphate

* Hand-formed is defined as a cranioplasty implant formed intra-operatively by the surgeon using no specialized tools

** Prefabricated is defined as a cranioplasty implant which has been manufactured independent from and prior-to the surgical procedure

*** Templated is defined as a cranioplasty implant formed intra-operatively by the surgeon using specialized, prefabricated tools.

It must be noted that the combined utilization of materials, size and cause of defect, overlying soft tissue coverage, patient characteristics and complications other than infection (such as extrusion and migration) were not considered as a part of this study. Whilst these are critical issues in examining the effectiveness and survivability of cranioplasty implants from a clinical view-point, the purpose of 
this study is to examine only infection risk and, as such, these components are excluded. However, they provide points for examination in future reviews.

The search was conducted using the following key words: cranioplasty, craniofacial, implant, material, manufacture, infection, failure, autologous bone, polymethylmethacrylate, PMMA, hand-formed, prefabricated, rapid templated, titanium plate, titanium mesh, hydroxyapatite, polyetheretherketone, polyethylene and calcium phosphate.

Each biomaterial was provided by the authors with an estimated interactive surface form ranking ("ISF") and a tissue attachment bioactivity ranking ("TAB"), based on material surface and bioactive properties. The ISF ranking is defined as a relative measure of interaction between the implant surface and the bodies tissues and immune system - where a higher ranking represents high interconnected porosity and, as a result, greater access to vascularized tissue ingrowth and the immune system-and the TAB ranking as a relative measure of the ability for a material to support attachment of growing tissue-where a higher ranking represents an increased support for tissue ingrowth. The purpose of these values is to provide a comparison point between implant material, manufacturing method, surface characteristics, bioactivity and infection potential. ISF and TAB rankings have been defined by the authors in Tables 1 and 2.

Table 1. Definition of interactive surface form (ISF) and tissue attachment bioactivity (TAB) rankings.

\begin{tabular}{cl}
\hline ISF Ranking & Definition \\
\hline 0 & Non-porous structure \\
1 & Mildly texture surface with minimal interconnected porosity \\
2 & Textured surface with mid-range interconnected porosity \\
3 & Full porous structure \\
\hline TAB Ranking & Definition \\
\hline 0 & No support for tissue attachment \\
1 & Little support for tissue attachment and little to no ingrowth \\
3 & Support of tissue ingrowth, integration and tissue attachment \\
\hline
\end{tabular}

Each material was provided with a relative risk value in order to provide a degree of comparison. In this review, autologous bone is considered as the gold standard, based on the consideration of full regeneration and integration as a potential patient outcome [12-15]. This calculation was taken as follows:

Table 2. Relative Risk Calculation Data.

\begin{tabular}{ccc}
\hline Risk of Infection & Implant Lost & Implant Retained \\
\hline Autologous Bone & $a$ & $b$ \\
Alternative Material & $c$ & $d$ \\
\hline
\end{tabular}

Therefore: Relative Risk $(R R)=(c /(c+d)) /(a /(a+b))$; Where an $R R<1=$ less likely than autologous bone to be lost through infection and $R R>1=$ more likely than autologous bone to be lost through infection.

Finally, a one-way ANOVA test was conducted in order to determine if there was any statistical significance between the mean infection rates for each implant material.

\section{Results}

A total of 58 publications were found to be relevant based on these key words. Based on the search inclusion criteria, 41 of the 58 studies were found to meet the requirements for examination in this review.

All data was extracted based on numerical data found in tables, figures and written body of the included publications, and amalgamated in order to overcome potential bias and provide data which 
represents an average infection risk for each material. In order to provide a comparison of implantable materials for cranioplasty and craniofacial reconstruction and to provide an evaluation of available data in regards to reconstruction material and potential infection risk, each selected material is examined independently and the results merged into a final comparison table to provide a holistic overview.

\subsection{Autologous Bone}

In total, 10 of the 41 studies provided data for autologous bone in relation to infection complication risk as per the selection criteria. Implant number varied between 20 and 138 implants. For the purposes of this paper, only autologous bone flaps were considered. Different methods of storage were amalgamated, as a holistic view of autologous bone was desired. This is shown in Table 3.

Table 3. Autologous bone.

\begin{tabular}{cccc}
\hline Paper & Number of Implants & Number of Infection & Average Infection Rate (\%) \\
\hline$[16]$ & 54 & 14 & 25.93 \\
{$[1]$} & 52 & 7 & 13.50 \\
{$[14]$} & 91 & 5 & 5.50 \\
{$[8]$} & 83 & 12 & 14.46 \\
{$[6]$} & 118 & 7 & 5.93 \\
{$[17]$} & 30 & 3 & 10.00 \\
{$[18]$} & 31 & 3 & 9.68 \\
{$[19]$} & 138 & 10 & 7.25 \\
{$[20]$} & 20 & 5 & 25.00 \\
{$[21]$} & 69 & 6 & 8.70 \\
Total: & 686 & 72 & 10.50 \\
Standard Deviation: & - & - & 7.03 \\
Relative Risk: & 1.00 & - & - \\
\hline
\end{tabular}

Infection rates varied between $5.93 \%$ and $25 \%$, with an average infection rate of $10.50 \%$, a standard deviation of $7.03 \%$ and a relative risk of 1 .

Autologous bone stands as an anomaly when we consider both ISF and TAB values. When we consider its nature, a direct reimplantation of removed host tissue, we note that it has high potential for complete reintegration given the lack of foreign material introduction [5]; providing the patient with a completely regenerative (in the sense that the host tissue is completely replaced) solution. As such, it can be considered to have a potential IMF and TAB value of 3, representing full integration and regeneration. However, literature highlights resorption of the autologous bone implant as a common issue known to impact the effectiveness of potential vascularization and reintegration [19,22], and as a result the autologous bone implant fails to reach the stage when reintegration is possible; shielded from the immune system it presents an ideal scaffold for bacteria and increasing risk of implant failure. As such, the IMF and TAB values, for the purposes of this study, can be considered as 0 .

\subsection{Polymethylmethacrylate (PMMA)}

In total, 19 of the 41 studies provided data for PMMA in relation to infection complication risk as per the selection criteria. This can be further split by manufacture method, examining PMMA (prefabricated), PMMA (hand-formed) and PMMA (templated). This is shown in Table 4. 
Table 4. (a) PMMA (Prefabricated); (b) PMMA (Hand-formed); (c) PMMA (Templated). PMMA: polymethylmethacrylate.

\begin{tabular}{|c|c|c|c|}
\hline \multicolumn{4}{|c|}{ (a) } \\
\hline Paper & Number of Implants & Number of Infections & Average Infection Rate (\%) \\
\hline [16] & 3 & 1 & 33.00 \\
\hline [14] & 17 & 1 & 5.88 \\
\hline [23] & 10 & 0 & 0.00 \\
\hline$[24]$ & 78 & 10 & 13.00 \\
\hline [18] & 13 & 0 & 0.00 \\
\hline [19] & 120 & 7 & 5.83 \\
\hline$[25]$ & 22 & 0 & 0.00 \\
\hline [26] & 11 & 0 & 0.00 \\
\hline Total: & 274 & 19 & 6.99 \\
\hline Standard Deviation: & - & - & 10.67 \\
\hline Relative Risk: & 0.66 & - & - \\
\hline \multicolumn{4}{|c|}{ (b) } \\
\hline [16] & 55 & 7 & 12.70 \\
\hline [14] & 23 & 3 & 13.00 \\
\hline [6] & 15 & 3 & 20.00 \\
\hline [17] & 19 & 2 & 10.53 \\
\hline [27] & 61 & 4 & 6.56 \\
\hline [20] & 11 & 3 & 27.27 \\
\hline$[28]$ & 98 & 9 & 9.18 \\
\hline Total: & 282 & 31 & 10.98 \\
\hline Standard Deviation: & - & - & 6.70 \\
\hline Relative Risk: & 1.05 & - & - \\
\hline \multicolumn{4}{|c|}{ (c) } \\
\hline [29] & 27 & 1 & 3.70 \\
\hline [30] & 28 & 2 & 7.14 \\
\hline [11] & 16 & 1 & 6.25 \\
\hline$[31]$ & 31 & 3 & 9.68 \\
\hline Total: & 102 & 7 & 6.86 \\
\hline Standard Deviation: & - & - & 2.14 \\
\hline Relative Risk: & 0.65 & - & - \\
\hline
\end{tabular}

\subsection{PMMA (Prefabricated)}

In total, 8 of the 41 studies provided data for PMMA (prefabricated) in relation to infection complication risk as per the selection criteria. Implant number varied between 3 and 120 implants.

Infection rates varied between $0.00 \%$ and $33.33 \%$, with an average infection rate of $6.99 \%$, a standard deviation of $10.67 \%$ and a relative risk of 0.66 .

\subsection{PMMA (Hand-Formed)}

In total, 7 of the 41 studies provided data for PMMA (hand-formed) in relation to infection complication risk as per the selection criteria. Implant number varied between 11 and 98 implants.

Infection rates varied between $6.56 \%$ and $27.27 \%$, with an average infection rate of $10.98 \%$, a standard deviation of $6.70 \%$ and a relative risk of 1.05 .

\subsection{PMMA (Templated)}

In total, 4 of the 41 studies provided data for PMMA (templated) in relation to infection complication risk as per the selection criteria. Implant number varied between 16 and 31 implants.

Infection rates varied between $3.70 \%$ and $9.68 \%$, with an average infection rate of $6.86 \%$, a standard deviation of $2.14 \%$ and a relative risk of 0.65 . 
PMMA implant manufacture produces surface textures ranging from smooth to coarse and can have varying degrees of porosity from $0 \%$ to $40 \%$ [32]. As such, the ISF ranking assigned to PMMA is 1. PMMA is a bioinert material and is shown to have very little natural support for attachment and ingrowth of tissue [32], however small holes may be bored into the implant to provide pathways for tissue growth [24]. Whilst these holes can allow some tissue connection through the implant, they are not considered to be an extensive and integral component of the PMMA implant. When we consider, in conjunction, that PMMA does not actively provide any native support for tissue ingrowth, the TAB value is considered as 0 .

\subsection{Titanium}

In total, 10 of the 41 studies provided data for titanium in relation to infection complication risk as per the selection criteria. This can be further split examining titanium (mesh) and titanium (plate). This is shown in Table 5.

Table 5. (a) Titanium mesh; (b) Titanium plate.

\begin{tabular}{cccc}
\hline & \multicolumn{2}{c}{$(\mathbf{a})$} & \\
\hline Paper & Number of Implants & Number of Infections & Average Infection Rate (\%) \\
\hline$[16]$ & 77 & 2 & 2.60 \\
{$[33]$} & 108 & 12 & 11.11 \\
{$[34]$} & 12 & 2 & 16.67 \\
{$[35]$} & 218 & 16 & 7.34 \\
Total: & 415 & 32 & 7.71 \\
Standard Deviation: & - & - & 5.21 \\
Relative Risk: & 0.73 & - & - \\
\hline & & & \\
\hline [36] & 26 & 0 & 0.00 \\
{$[27]$} & 65 & 7 & 70.77 \\
{$[37]$} & 95 & 7 & 3.37 \\
{$[38]$} & 151 & 6 & 14.17 \\
[39] & 127 & 18 & 8.62 \\
Total: & 174 & 15 & 8.31 \\
Standard Deviation: & 638 & 53 & 4.58 \\
Relative Risk: & - & - & - \\
\hline
\end{tabular}

\subsection{Titanium (Mesh)}

In total, 4 of the 41 studies provided data for titanium (mesh) in relation to infection complication risk as per the selection criteria. Implant number varied between 12 and 218 implants.

Infection rates varied between $2.60 \%$ and $16.67 \%$, with an average infection rate of $7.71 \%$, a standard deviation of $5.21 \%$ and a relative risk of 0.73 .

\subsection{Titanium (Plate)}

In total, 6 of the 41 studies provided data for titanium (plate) in relation to infection complication risk as per the selection criteria. Implant number varied between 26 and 174 implants.

Infection rates varied between $0.00 \%$ and $14.17 \%$, with an average infection rate of $8.31 \%$, a standard deviation of $4.58 \%$ and a relative risk of 0.79 .

Titanium is a versatile metal and, in the field of cranioplasty, finds usage in a number of different structural forms. Titanium is considered a bioactive metal, with strong potential of osseointegration given appropriate porosity and surface texture [41,42]. Titanium plate, however, has no porosity and does not provide a surface adequate for tissue ingrowth; it is given both an ISF ranking and a TAB ranking of 0 . Titanium mesh, however, does provide a greater degree of integration potential [43], 
and is given an ISF ranking of 1. Like titanium plate, the smooth nature of the mesh itself does not promote ingrowth into the material, but rather into the surrounding space. As such, a TAB ranking of 0 is provided to titanium mesh.

\subsection{Hydroxyapatite (HA)}

In total, 5 of the 41 studies provided data for HA in relation to infection complication risk as per the selection criteria. Implant number varied between 25 and 1608 implants. This is shown in Table 6 .

Table 6. Hydroxyapatite (HA).

\begin{tabular}{cccc}
\hline Paper & Number of Implants & Number of Infections & Average Infection Rate (\%) \\
\hline$[18]$ & 50 & 1 & 2.00 \\
{$[44]$} & 51 & 1 & 1.96 \\
{$[20]$} & 31 & 1 & 3.23 \\
{$[45]$} & 1608 & 33 & 2.05 \\
{$[46]$} & 25 & 0 & 0.00 \\
Total: & 1765 & 36 & 2.04 \\
Standard Deviation: & - & - & 1.04 \\
Relative Risk: & 0.19 & - & - \\
\hline
\end{tabular}

Infection rates varied between $0.00 \%$ and $2.05 \%$, with an average infection rate of $2.04 \%$, a standard deviation of $1.04 \%$ and a relative risk of 0.19 .

HA cranioplasty implants are praised for their regenerative and integrative potential, having a high degree of tissue ingrowth and vascularization [46-53]. Given these properties, and the materials highly porous nature it is given an ISF rank of 3 and TAB rank of 2.

\subsection{Polyetheretherketone (PEEK)}

In total, 8 of the 41 studies provided data for PEEK in relation to infection complication risk as per the selection criteria. Implant number varied between 2 and 66 implants. This is shown in Table 7.

Table 7. Polyetheretherketone (PEEK).

\begin{tabular}{cccc}
\hline Paper & Number of Implants & Number of Infections & Average Infection Rate (\%) \\
\hline$[54]$ & 12 & 0 & 0.00 \\
{$[33]$} & 24 & 2 & 8.33 \\
{$[18]$} & 2 & 0 & 0.00 \\
{$[55]$} & 66 & 5 & 7.58 \\
{$[56]$} & 22 & 2 & 9.09 \\
{$[57]$} & 14 & 2 & 14.29 \\
{$[20]$} & 2 & 0 & 0.00 \\
{$[35]$} & 10 & 1 & 10.00 \\
Total: & 152 & 12 & 7.89 \\
Standard Deviation: & - & - & 5.16 \\
Relative Risk: & 0.75 & - & - \\
\hline
\end{tabular}

Infection rates varied between $0.00 \%$ and $14.29 \%$, with an average infection rate of $7.89 \%$, a standard deviation of $5.16 \%$ and a relative risk of 0.75 .

For cranioplasty applications, PEEK tends to be manufactured with a smooth surface. In addition, its hydrophobic properties are such that concerns exist in regards to the materials anatomical integration potential $[53,58,59]$, as such, both the ISF and TAB ranking can be considered to be 0 . 


\subsection{Polyethylene (PE)}

In total, 5 of the 41 studies provided data for PE in relation to infection complication risk as per the selection criteria. Implant number varied between 7 and 69 implants. This is shown in Table 8 .

Table 8. Polyethylene (PE).

\begin{tabular}{cccc}
\hline Paper & Number of Implants & Number of Infection & Average Infection Rate (\%) \\
\hline$[8]$ & 12 & 0 & 0.00 \\
{$[6]$} & 7 & 1 & 14.29 \\
{$[60]$} & 69 & 5 & 7.25 \\
{$[20]$} & 7 & 0 & 0.00 \\
{$[61]$} & 23 & 1 & 4.35 \\
Total: & 118 & 7 & 5.93 \\
Standard Deviation: & - & - & 5.33 \\
Relative Risk: & 0.57 & - & - \\
\hline
\end{tabular}

Infection rates varied between $0.00 \%$ and $14.29 \%$, with an average infection rate of $5.93 \%$, a standard deviation of $5.33 \%$ and a relative risk of 0.57 .

One of most common form of PE used in cranioplasty applications is a porous mesh form $[43,60,61]$. The implant itself is a highly porous structure and is given an ISF ranking of 3 . However, as a bioinert material PE does not actively promote tissue ingrowth or regeneration [62], although it can take a more bioactive role upon coating with bioactive materials [63]. However, given its natural characteristics, PE is provided with a TAB ranking of 0 .

\subsection{Calcium Phosphate}

In total, 3 of the 41 studies provided data for calcium phosphate in relation to infection complication risk as per the selection criteria. Implant number varied between 16 and 92 implants. This is shown in Table 9.

Table 9. Calcium Phosphate.

\begin{tabular}{cccc}
\hline Paper & Number of Implants & Number of Infections & Average Infection Rate (\%) \\
\hline$[64]$ & 92 & 0 & 0.00 \\
{$[65]$} & 71 & 9 & 12.68 \\
[66] & 16 & 3 & 18.75 \\
Total: & 179 & 12 & 6.70 \\
Standard Deviation: & - & - & 8.04 \\
Relative Risk: & 0.64 & - & - \\
\hline
\end{tabular}

Infection rates varied between $0.00 \%$ and $18.75 \%$, with an average infection rate of $6.70 \%$, a standard deviation of $8.04 \%$ and a relative risk of 0.64 .

Much like HA, calcium phosphate cranioplasty implants are considered to have strong regenerative and reintegration properties. Given these properties, and the materials relatively porous nature $[66,67]$ it is given and ISF rank of 2 and TAB rank of 2.

Table 10 and Figure 1 provide a source of comparison between material, manufacturing method (where applicable), infection rate, estimated ISF and TAB values and relative risk. This table highlights variation between materials in regards to total infection risk, however, depending on the materials compared, this value may be insignificant. 
Table 10. Cranioplasty/craniofacial implant material: comparison of associated infection risk, surface form and tissue attachment.

\begin{tabular}{ccccccc}
\hline Material & $\begin{array}{c}\text { Number of } \\
\text { Implants }\end{array}$ & $\begin{array}{c}\text { Number of } \\
\text { Infections }\end{array}$ & $\begin{array}{c}\text { Average } \\
\text { Infection } \\
\text { Rate (\%) }\end{array}$ & $\begin{array}{c}\text { Interactive } \\
\text { Surface Form } \\
\text { (“ISF”) }\end{array}$ & $\begin{array}{c}\text { Tissue Attachment } \\
\text { Bioactivity Rank } \\
\text { (“TAB”) }\end{array}$ & $\begin{array}{c}\text { Relative } \\
\text { Risk }\end{array}$ \\
\hline $\begin{array}{c}\text { Autologous } \\
\text { Bone* }\end{array}$ & 686 & 72 & 10.5 & 0 & 0 & 1.00 \\
\hline $\begin{array}{c}\text { PMMA } \\
\text { (hand-formed) }\end{array}$ & 282 & 31 & 10.98 & 0 & 0 & 0 \\
\hline Titanium (plate) & 638 & 53 & 8.31 & 0 & 0 & 0.79 \\
\hline PEEK & 152 & 12 & 7.89 & 0 & 0 & 0.75 \\
\hline Titanium (mesh) & 415 & 32 & 7.71 & 1 & 0 & 0.73 \\
\hline $\begin{array}{c}\text { PMMA } \\
\text { (prefabricated) }\end{array}$ & 274 & 19 & 6.99 & 0 & 0 & 0.66 \\
\hline $\begin{array}{c}\text { PMMA } \\
\text { (templated) }\end{array}$ & 102 & 7 & 6.86 & 1 & 2 & 0.64 \\
\hline Calcium-Phosphate & 179 & 12 & 6.7 & 2 & 0 & 0.57 \\
\hline PE & 118 & 7 & 5.93 & 10.5 & 0 & 0 \\
\hline HA & 1765 & 36 & 3 & 0.19 \\
\hline
\end{tabular}

${ }^{*}$ Indicates implant formation via direct handling of the implant material in surgery; ${ }^{+}$Indicates implant formation via custom molding template in surgery.

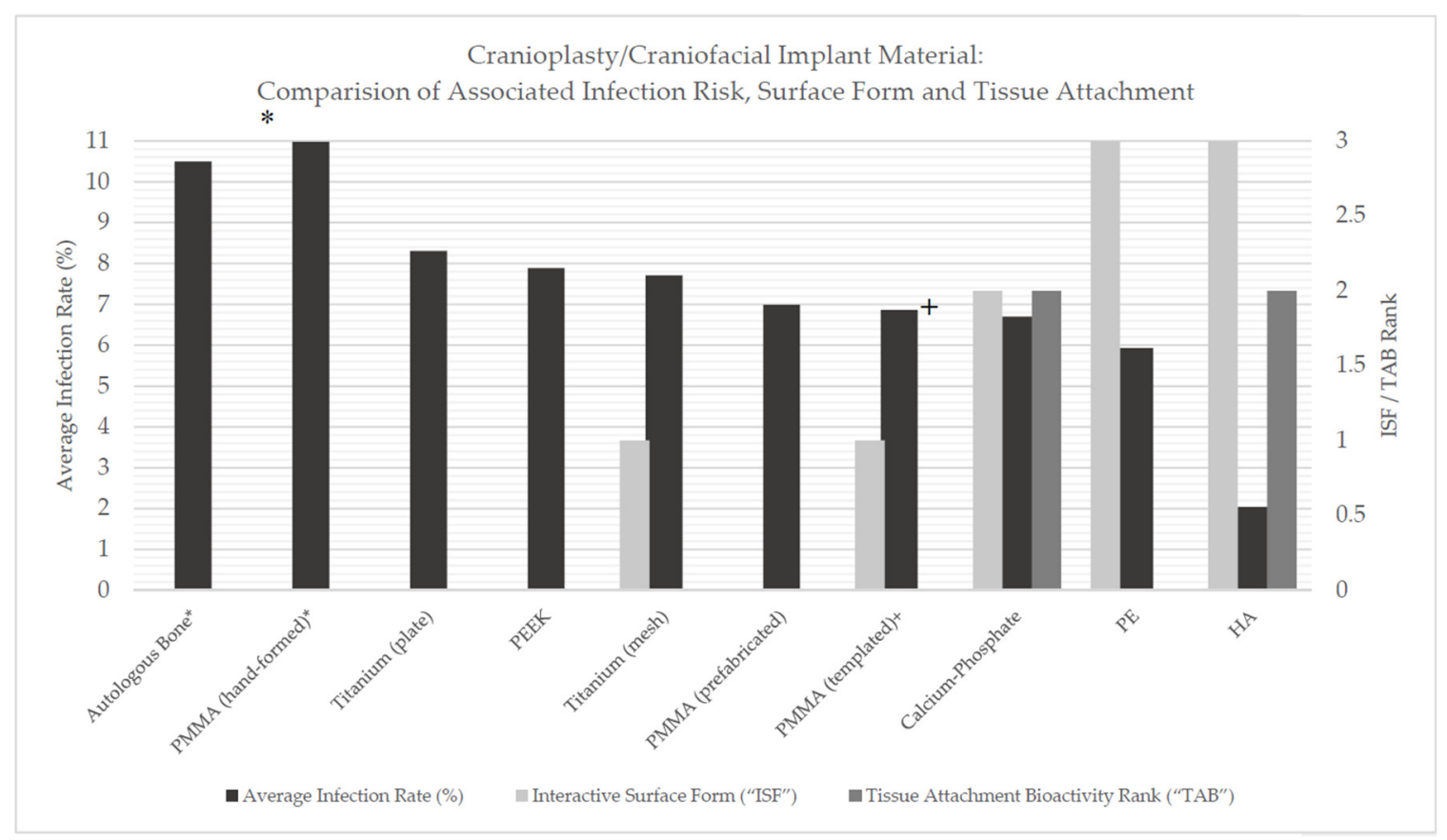

Figure 1. Cranioplasty/craniofacial implant material: comparison of associated infection risk, surface form and tissue attachment. ${ }^{*}$ Indicates implant formation via direct handling of the implant material in surgery; ${ }^{+}$Indicates implant formation via custom molding template in surgery.

Table 11 highlights the results of the one-way ANOVA test conducted. 
Table 11. One-way analysis of variance (ANOVA) test for statistical significance between all examined implant materials and associated average infection rate.

\begin{tabular}{ccccccc}
\hline $\begin{array}{c}\text { Source of } \\
\text { Variation }\end{array}$ & $\begin{array}{c}\text { Sum of } \\
\text { Squares }\end{array}$ & $\begin{array}{c}\text { Degrees of } \\
\text { Freedom }\end{array}$ & $\begin{array}{c}\text { Mean } \\
\text { Square }\end{array}$ & F & $\boldsymbol{p}$-Value & F Crit \\
\hline $\begin{array}{c}\text { Between Groups } \\
\text { Total: }\end{array}$ & 761.11 & 9 & 84.57 & 1.69 & 0.12 & 2.07 \\
\hline
\end{tabular}

There were not found to be statistically significant differences between all implant material infection rate means as ascertained by one-way ANOVA $(p=0.12)$.

\section{Discussion}

When we consider a comparison of the infection rate of different biomaterials, it is fundamental to recognize differences in material characteristics: material properties, biocompatibility, bioactivity etc.

Autologous bone is considered as having the potential to provide an immediate patient specific implant, providing a repair solution with no manufacturing requirements. Key advantages of use lie in high immunological compatibility [36], as the implant is comprised of the patient's own tissue, as well as superior anatomical cosmesis, given it matches the injury profile directly [29]. Often, direct re-implantation of the autologous bone flap is not feasible and storage (either cryogenic or subcutaneous) is required to ensure the flap is preserved until re-implantation $[21,68,69]$. Whilst functional, these methods may not provide adequate storage, with infection and resorption potential rendering the autologous flap unusable $[19,21,70]$.

PMMA is a medically accepted thermoplastic with high compatibility. It finds common use as a grout-like-material or for lost bone remodeling [24,25,28,71,72]. Whilst PMMA is a biocompatible material, the raw methyl methacrylate component is a potential irritant [73]. The curing process for PMMA is exothermic (between 70 and $120^{\circ} \mathrm{C}$ ). This has significant implications for in vitro use, as such temperatures can lead to death of surrounding tissue through thermal necrosis [74-76]. In addition, there is evidence which suggests that the curing process of PMMA can lead to cardiopulmonary complications (hypotension) [77]. However, these properties are tied directly to the shaping and curing of PMMA within the body (hand-formation) and can be minimized effectively through pre-surgical fabrication (prefabrication) or intraoperative molding external to the patient (templating).

Titanium is well established in the field of cranial and craniofacial medicine. This is primarily due to its biological inertness, favorable strength-to-weight ratio and favorable cosmetic and functional outcomes [36,38,39,78]. Another key advantage of titanium is its natural osseointegration factor, which promotes active bone growth into the implant [41,42]. Studies have shown that titanium implants for cranial and maxillofacial applications have a lower survival rate (higher complication rate) than alterative materials such as PMMA [27]. Despite its lower Young's modulus than alterative metals, the value for titanium is higher than that of natural bone, leading to a lessened, but still present, risk of stress shielding [79]. Titanium implants will often require pre-fabrication [39,78], leading to an increase lead time and cost. In addition, intraoperative alteration remains difficult [80].

Hydroxyapatite (HA) is a natural inorganic mineral compound found naturally in human teeth and bone tissue and, as such, represents a prime candidate for orthopedic applications, acting as both a filer for replacing lost bone [46-53] and as a coating for implantable structures to promote bone ingrowth [52,53]. HA is not capable of withstanding high loads and, as such, is not as suited for larger defects when compared to other implantable materials [4,5]. HA remains relatively costly when compared to other non-metal implant materials [3]. It must be noted that HA has numerous advantages when combined with alternative materials, as the benefits of its bioactive, pro-osseointegration properties are accompanied by a more rigid and stable structure [49,52], however, this is not a consideration in this review. 
Polyetheretherketone (PEEK) is a biocompatible linear thermoplastic which is finding increased acceptance in the medical industry as an alternative to metal components. The core driving factor to the development of PEEK as a biomaterial was the need to balance strength and rigidity: to develop an implant system which met the structural strength requirements of the body, whilst minimizing rigidity in an attempt to reduce stress shielding risk $[33,81]$. Traditionally PEEK found use in spinal treatment applications, as well as cranial and maxillofacial applications $[54,56,82]$. It must be noted that PEEK is a hydrophobic material. As such, it does not actively bond to tissue, creating potential issues in regards to anatomical integration as bone cells will not bond to the implants [59]. Whilst there are a number of coatings which can alleviate these concerns [53,58], un-coated PEEK remains at a disadvantage in regards to achieving stable fixation in a short timeframe.

Polyethylene is a thermoplastic material which finds use in numerous areas of the medical industry. This is due to its variability and adaptability, as its method of manufacture and formation can give it various physical properties tailoring it for a broad range of applications, from medical packaging to implants [83]. It can be manufactured as a porous structure, commonly used in cranioplasty applications, allowing for the creation of semi-rigid structures which are both strong and flexible and allow for alteration with minimal effort $[60,84,85]$. It must be noted that for certain applications such porous structures this material may not have the mechanical properties to act in load-bearing structures [86,87].

Calcium phosphate bone cements are finding acceptance as methods of cranial reconstruction given their strong biocompatibility and osteoconductive nature [66]. In addition, ready availability and ease of use present calcium phosphate cements as appealing alternatives to current reconstruction materials [67].

Based on the findings from the systematic review, the following can be inferred from the results:

- Implant material/manufacturing method has an effect on infection risk.

Whilst the results of the one-way ANOVA $(p=0.12)$ show no statistical significance when analyzing all implant materials as a whole, analysis of means highlights variation between individual implant materials and manufacturing methods; which, dependent on the materials compared directly, can be considered significant.

Further literature analysis highlights the following factors as prime sources of increased infection and complication risk for cranial and craniofacial implants.

- Latency Period between Tissue Removal and Implant $[1,8]$

- The literature suggests that a necessary latency period, from initial flap removal to implantation of the desired implant, may lead to a lower infection risk.

- Previous Multiple Operations/Recent Operation [1,9]

○ The literature suggests that a higher number of operations can lead to a higher risk of infection. Additionally, short timeframes between surgeries are considered to further increase infection risk.

- $\quad$ Increased Surgical Time $[6,10,11]$

- The literature suggests that increased surgical time dramatically increases the risk of infection. Longer surgical times (greater than $4 \mathrm{~h}$ ) were associated with a higher risk of infection.

Additional factors, including gender, pre-existing infection, surgical errors, surgical complexity and poor outcomes, were also considered to potentially lead to an increase in infection potential. Infection risk can be further impacted through factors such as implant and defect size, fixation position 
and fixation stability. However, like the inherent infection resistance of implant materials, these factors were considered to have a lesser impact on potential risk than the aforementioned prime sources.

A reflection to be made from this examination is that implant material does provide an effect on potential infection risk, as greater levels of surface interaction and active support of tissue ingrowth can be considered as indicators of greater infection resistance. This can be seen as occurring in part due to the capacity of increased vascularization and access for the body's natural system to access the implant and assist in either preventing and/or combating possible sources of infection. Such characteristics are due to the physical structures of the implants and, as a result, it can be said that the method of production can, through alteration of these physical properties, assist in minimizing implant infection risk. It is to be noted that interconnected porosity is fundamental in tissue regeneration as this allows propagation of appropriate cells (osteoblasts) through the implant and the eventual formation of appropriate vascularization. Whilst the size of the pores may vary, it is generally accepted that a pore size of approximately $100 \mu \mathrm{m}$ is required to regenerate bone tissue [88]. As such, a trend can be seen where those implant materials with higher ISF and TAB rankings trend towards a lower infection risk; however, the true validity of this remains a point for future study.

Building on this, manufacturing methods can further minimize infection risk through influences of prime sources of infection risk. By removing the implant contouring and/or alteration requirements from cranioplasty/craniofacial repair, the processes become simplified, providing better outcomes with fewer surgical requirements. Using the example of PMMA implants for cranioplasty and craniofacial reconstruction, it can be observed that both the prefabricated and templated methods of implant production are considered to minimize potential surgical timeframes, whilst also reducing variance in surgical time between surgeries. This is reflected particularly in relation to the templating method by Kim et al. 2012, with cranioplasty surgery taking $184.36 \pm 26.07 \mathrm{~min}$ for PMMA (templated), as opposed to previously recorded values of $285 \pm 128 \mathrm{~min}$ for alternative fabrication methods [11]. The ability to either prefabricate patient specific implants, or template these intra-operatively external to the patient, provided clear benefits by removing the risk of thermal necrosis or hypotension associated with the curing process of PMMA [74-77]. In addition, the nature of geometry generation becomes controlled through accepted physical design methodologies and computer-aided design (CAD), allowing for better form, fit and function [26,89,90]; which in turn leads to less chance of abnormal biomechanics and fit-based complications, without the need to shape or alter the implant by hand, as well as minimizing the complexity of the surgical procedure. This example can be considered in the case of easily alterable materials (PMMA, porous polyethylene, titanium mesh, etc.) which can be readily shaped using commonly available surgical tools $[11,25,84,85,91]$ and adapted to meet anatomical requirements which may not be visible or known prior to surgery. However, for certain applications, such as titanium plate, this is not appropriate as intraoperative alteration of the implant is near impossible without specialized tools.

A fundamental consideration not discussed within the body of this review is the relationship between implant graft material and patient context. Different injury profiles and patient lifestyles require different outcomes, which may provide a degree of preference to certain reconstructive materials. Features such as size, shape, cause, complexity and functional outcomes can drastically impact the pool of applicable implant materials and the potential associated fabrication and implantation cost. However, this topic is beyond the scope of this review.

It is key to note that each study analyzed within this review portrayed varying results for infection rate for each material examined, with standard deviations within each material category ranging from 1.04 to 10.67. In addition, each study examined a different number of patients and overall sample sizes for each material category varied significantly, ranging from 2 to 1608 . As such, this raises the point that clinical studies may not present enough data individually in order to provide significant evidence of a material or methods utility over potential alternatives. This does not mean that clinical studies are ineffective, but rather aims to emphasize that collaboratively clinical studies can increase our understanding of how materials science impacts patient outcomes to a greater extent. 


\section{Conclusions}

The results of this review present variation between materials in regards to total infection risk, however, depending on the materials compared, this value may be insignificant. Alternative risk factors associated with infection, such as increased surgical time, number of revisions and time between revisions have a greater impact on infection potential than material variation and often material choice is facilitated by factors beyond infection; such as accessibility and patient context. However, it must be noted that implant material does provide an effect on potential infection risk, and trends can be observed showing greater levels of surface interaction and active support of tissue ingrowth as indicators of greater infection resistance. Such characteristics are due to the physical structures of the implants and, as a result, it can be said that the manufacturing methods can influence biomedical materials to assist in minimizing implant infection risk.

Conflicts of Interest: The authors declare no conflict of interest.

\section{References}

1. Cheng, Y.-K.; Weng, H.-H.; Yang, J.-T.; Lee, M.-H.; Wang, T.-C.; Chang, C.-N. Factors affecting graft infection after cranioplasty. J. Clin. Neurosci. 2008, 15, 1115-1119. [CrossRef] [PubMed]

2. Elias, C.N.; Lima, J.H.; Valiev, R.; Meyers, M.A. Biomedical applications of titanium and its alloys. JOM 2008, 60, 46-49. [CrossRef]

3. Engstrand, T. Biomaterials and biologics in craniofacial reconstruction. J. Craniofac. Surg. 2012, 23, 239-242. [CrossRef] [PubMed]

4. Aydin, S.; Kucukyuruk, B.; Abuzayed, B.; Aydin, S.; Sanus, G.Z. Cranioplasty: Review of materials and techniques. J. Neurosci. Rural Pract. 2011, 2, 162-167. [PubMed]

5. Shah, A.M.; Jung, H.; Skirboll, S. Materials used in cranioplasty: A history and analysis. Neurosurg. Focus 2014, 36, E19. [CrossRef] [PubMed]

6. Lee, C.-H.; Chung, Y.-S.; Lee, S.-H.; Yang, H.-J.; Son, Y.-J. Analysis of the factors influencing bone graft infection after cranioplasty. J. Trauma Acute Care Surg. 2012, 73, 255-260. [CrossRef] [PubMed]

7. Mundinger, G.S.; Latham, K.; Friedrich, J.; Louie, O.; Said, H.; Birgfeld, C.; Ellenbogen, R.; Hopper, R.A. Management of the Repeatedly Failed Cranioplasty Following Large Postdecompressive Craniectomy: Establishing the Efficacy of Staged Free Latissimus Dorsi Transfer/Tissue Expansion/Custom Polyetheretherketone Implant Reconstruction. J. Craniofac. Surg. 2016, 27, 1971-1977. [CrossRef] [PubMed]

8. Im, S.H.; Jang, D.K.; Han, Y.M.; Kim, J.T.; Chung, D.S.; Park, Y.S. Long-term incidence and predicting factors of cranioplasty infection after decompressive craniectomy. J. Korean Neurosurg. Soc. 2012, 52, 396-403. [CrossRef] [PubMed]

9. Reddy, S.; Khalifian, S.; Flores, J.M.; Bellamy, J.; Manson, P.N.; Rodriguez, E.D.; Dorafshar, A.H. Clinical outcomes in cranioplasty: Risk factors and choice of reconstructive material. Plast. Reconstr. Surg. 2014, 133, 864-873. [CrossRef] [PubMed]

10. Gooch, M.R.; Gin, G.E.; Kenning, T.J.; German, J.W. Complications of cranioplasty following decompressive craniectomy: Analysis of 62 cases. Neurosurg. Focus 2009, 26, E9. [CrossRef] [PubMed]

11. Kim, B.J.; Hong, K.S.; Park, K.J.; Park, D.H.; Chung, Y.G.; Kang, S.H. Customized cranioplasty implants using three-dimensional printers and polymethyl-methacrylate casting. J. Korean Neurosurg. Soc. 2012, 52, 541-546. [CrossRef] [PubMed]

12. Neovius, E.; Engstrand, T. Craniofacial reconstruction with bone and biomaterials: Review over the last 11 years. J. Plast. Reconstr. Aesthet. Surg. 2010, 63, 1615-1623. [CrossRef] [PubMed]

13. Lemée, J.-M.; Petit, D.; Splingard, M.; Menei, P. Autologous bone flap versus hydroxyapatite prosthesis in first intention in secondary cranioplasty after decompressive craniectomy: A French medico-economical study. Neurochirurgie 2013, 59, 60-63. [CrossRef] [PubMed]

14. Lee, S.-C.; $\mathrm{Wu}$, C.-T.; Lee, S.-T.; Chen, P.-J. Cranioplasty using polymethyl methacrylate prostheses. J. Clin. Neurosci. 2009, 16, 56-63. [CrossRef] [PubMed] 
15. Gilardino, M.S.; Karunanayake, M.; Al-Humsi, T.; Izadpanah, A.; Al-Ajmi, H.; Marcoux, J.; Atkinson, J.; Farmer, J.P. A comparison and cost analysis of cranioplasty techniques: Autologous bone versus custom computer-generated implants. J. Craniofac. Surg. 2015, 26, 113-117. [CrossRef] [PubMed]

16. Matsuno, A.; Tanaka, H.; Iwamuro, H.; Takanashi, S.; Miyawaki, S.; Nakashima, M.; Nakaguchi, H.; Nagashima, T. Analyses of the factors influencing bone graft infection after delayed cranioplasty. Acta Neurochir. 2006, 148, 535-540. [CrossRef] [PubMed]

17. Bobinski, L.; Koskinen, L.-O.D.; Lindvall, P. Complications following cranioplasty using autologous bone or polymethylmethacrylate-Retrospective experience from a single center. Clin. Neurol. Neurosurg. 2013, 115, 1788-1791. [CrossRef] [PubMed]

18. Iaccarino, C.; Viaroli, E.; Fricia, M.; Serchi, E.; Poli, T.; Servadei, F. Preliminary results of a prospective study on methods of cranial reconstruction. J. Oral Maxillofac. Surg. 2015, 73, 2375-2378. [CrossRef] [PubMed]

19. Klinger, D.R.; Madden, C.; Beshay, J.; White, J.; Gambrell, K.; Rickert, K. Autologous and acrylic cranioplasty: A review of 10 years and 258 cases. World Neurosurg. 2014, 82, e525-e530. [CrossRef] [PubMed]

20. Piitulainen, J.M.; Kauko, T.; Aitasalo, K.M.; Vuorinen, V.; Vallittu, P.K.; Posti, J.P. Outcomes of cranioplasty with synthetic materials and autologous bone grafts. World Neurosurg. 2015, 83, 708-714. [CrossRef] [PubMed]

21. Inamasu, J.; Kuramae, T.; Nakatsukasa, M. Does difference in the storage method of bone flaps after decompressive craniectomy affect the incidence of surgical site infection after cranioplasty? Comparison between subcutaneous pocket and cryopreservation. J. Trauma Acute Care Surg. 2010, 68, 183-187. [CrossRef] [PubMed]

22. Lee, S.H.; Yoo, C.J.; Lee, U.; Park, C.W.; Lee, S.G.; Kim, W.K. Resorption of autogenous bone graft in cranioplasty: Resorption and reintegration failure. Korean J. Neurotrauma 2014, 10, 10-14. [CrossRef] [PubMed]

23. Rotaru, H.; Stan, H.; Florian, I.S.; Schumacher, R.; Park, Y.-T.; Kim, S.-G. Cranioplasty with custom-made implants: Analyzing the cases of 10 patients. J. Oral Maxillofac. Surg. 2012, 70, e169-e176. [CrossRef] [PubMed]

24. Jaberi, J.; Gambrell, K.; Tiwana, P.; Madden, C.; Finn, R. Long-term clinical outcome analysis of poly-methyl-methacrylate cranioplasty for large skull defects. J. Oral Maxillofac. Surg. 2013, 71, e81-e88. [CrossRef] [PubMed]

25. Huang, G.J.; Zhong, S.; Susarla, S.M.; Swanson, E.W.; Huang, J.; Gordon, C.R. Craniofacial reconstruction with Poly (Methyl Methacrylate) customized cranial implants. J. Craniofac. Surg. 2015, 26, 64-70. [CrossRef] [PubMed]

26. Turgut, G.; Özkaya, Ö.; Kayal, M.U. Computer-aided design and manufacture and rapid prototyped polymethylmethacrylate reconstruction. J. Craniofac. Surg. 2012, 23, 770-773. [CrossRef] [PubMed]

27. Al-Tamimi, Y.Z.; Sinha, P.; Trivedi, M.; Robson, C.; Al-Musawi, T.A.; Hossain, N.; Mumford, C.; Towns, G. Comparison of acrylic and titanium cranioplasty\#. Br. J. Neurosurg. 2012, 26, 510-513. [PubMed]

28. Marchac, D.; Greensmith, A. Long-term experience with methylmethacrylate cranioplasty in craniofacial surgery. J. Plast. Reconstr. Aesthet. Surg. 2008, 61, 744-752. [CrossRef] [PubMed]

29. Marbacher, S.; Andereggen, L.; Erhardt, S.; Fathi, A.R.; Fandino, J.; Raabe, A.; Beck, J. Intraoperative template-molded bone flap reconstruction for patient-specific cranioplasty. Neurosurg. Rev. 2012, 35, 527-535. [CrossRef] [PubMed]

30. Stieglitz, L.H.; Gerber, N.; Schmid, T.; Mordasini, P.; Fichtner, J.; Fung, C.; Murek, M.; Weber, S.; Raabe, A.; Beck, J. Intraoperative fabrication of patient-specific moulded implants for skull reconstruction: Single-centre experience of 28 cases. Acta Neurochir. 2014, 156, 793-803. [CrossRef] [PubMed]

31. Goh, R.C.; Chang, C.N.; Lin, C.L.; Lo, L.J. Customised fabricated implants after previous failed cranioplasty. J. Plast. Reconstr. Aesthet. Surg. 2010, 63, 1479-1484. [CrossRef] [PubMed]

32. Eppley, B.L. Biomechanical testing of alloplastic PMMA cranioplasty materials. J. Craniofac. Surg. 2005, 16, 140-143. [CrossRef] [PubMed]

33. Thien, A.; King, N.K.; Ang, B.T.; Wang, E.; Ng, I. Comparison of Polyetheretherketone and Titanium Cranioplasty after Decompressive Craniectomy. World Neurosurg. 2015, 83, 176-180. [CrossRef] [PubMed]

34. Kshettry, V.R.; Hardy, S.; Weil, R.J.; Angelov, L.; Barnett, G.H. Immediate titanium cranioplasty after debridement and craniectomy for postcraniotomy surgical site infection. Neurosurgery 2012, 70, ons8-ons15. [CrossRef] 
35. Lee, E.I.; Chao, A.H.; Skoracki, R.J.; Yu, P.; DeMonte, F.; Hanasono, M. Outcomes of calvarial reconstruction in cancer patients. Plast. Reconstr. Surg. 2014, 133, 675-682. [CrossRef] [PubMed]

36. Cabraja, M.; Klein, M.; Lehmann, T.N. Long-term results following titanium cranioplasty of large skull defects. Neurosurg. Focus 2009, 26, E10. [CrossRef] [PubMed]

37. Hill, C.S.; Luoma, A.M.V.; Wilson, S.R.; Kitchen, N. Titanium cranioplasty and the prediction of complications. Br. J. Neurosurg. 2012, 26, 832-837. [CrossRef] [PubMed]

38. Williams, L.; Fan, K.; Bentley, R. Custom-made titanium cranioplasty: Early and late complications of 151 cranioplasties and review of the literature. Int. J. Oral Maxillofac. Surg. 2015, 44, 599-608. [CrossRef] [PubMed]

39. Wiggins, A.; Austerberry, R.; Morrison, D.; Ho, K.M.; Honeybul, S. Cranioplasty with custom-made titanium plates-14 years experience. Neurosurgery 2013, 72, 248-256. [CrossRef] [PubMed]

40. Mukherjee, S.; Thakur, B.; Haq, I.; Hettige, S.; Martin, A.J. Complications of titanium cranioplasty-A retrospective analysis of 174 patients. Acta Neurochir. 2014, 156, 989-998. [CrossRef] [PubMed]

41. Le Guéhennec, L.; Soueidan, A.; Layrolle, P.; Amouriq, Y. Surface treatments of titanium dental implants for rapid osseointegration. Dent. Mater. 2007, 23, 844-854. [CrossRef] [PubMed]

42. Salou, L.; Hoornaert, A.; Louarn, G.; Layrolle, P. Enhanced osseointegration of titanium implants with nanostructured surfaces: An experimental study in rabbits. Acta Biomater. 2015, 11, 494-502. [CrossRef] [PubMed]

43. Janecka, I.P. New reconstructive technologies in skull base surgery: Role of titanium mesh and porous polyethylene. Arch. Otolaryngol. Head Neck Surg. 2000, 126, 396-401. [CrossRef] [PubMed]

44. Staffa, G.; Barbanera, A.; Faiola, A.; Fricia, M.; Limoni, P.; Mottaran, R.; Zanotti, B.; Stefini, R. Custom made bioceramic implants in complex and large cranial reconstruction: A two-year follow-up. J. Cranio-Maxillofac. Surg. 2012, 40, e65-e70. [CrossRef] [PubMed]

45. Stefini, R.; Esposito, G.; Zanotti, B.; Iaccarino, C.; Fontanella, M.; Servadei, F. Use of "custom made" porous hydroxyapatite implants for cranioplasty: Postoperative analysis of complications in 1549 patients. Surg. Neurol. Int. 2013, 4, 12. [CrossRef] [PubMed]

46. Staffa, G.; Nataloni, A.; Compagnone, C.; Servadei, F. Custom made cranioplasty prostheses in porous hydroxy-apatite using 3D design techniques: 7 years experience in 25 patients. Acta Neurochir. 2007, 149, 161-170. [CrossRef] [PubMed]

47. Burstein, F.D.; Cohen, S.R.; Hudgins, R.; Boydston, W.; Simms, C. The use of hydroxyapatite cement in secondary craniofacial reconstruction. Plast. Reconstr. Surg. 1999, 104, 1270-1275. [CrossRef] [PubMed]

48. Choi, S.H.; Levy, M.L.; McComb, J.G. A method of cranioplasty using coralline hydroxyapatite. Pediatr. Neurosurg. 1998, 29, 324-327. [CrossRef] [PubMed]

49. Ducic, Y. Titanium mesh and hydroxyapatite cement cranioplasty: A report of 20 cases. J. Oral Maxillofac. Surg. 2002, 60, 272-276. [CrossRef] [PubMed]

50. Durham, S.R.; McComb, J.G.; Levy, M.L. Correction of large $\left(>25 \mathrm{~cm}^{2}\right)$ cranial defects with "reinforced" hydroxyapatite cement: Technique and complications. Neurosurgery 2003, 52, 842-845. [CrossRef] [PubMed]

51. Pang, D.; Tse, H.H.; Zwienenberg-Lee, M.; Smith, M.; Zovickian, J. The combined use of hydroxyapatite and bioresorbable plates to repair cranial defects in children. J. Neurosurg. Pediatr. 2005, 102, 36-43. [CrossRef] [PubMed]

52. Gupta, A.; Tripathi, G.; Lahiri, D.; Balani, K. Compression molded ultra high molecular weight polyethylene-hydroxyapatite-aluminum oxide-carbon nanotube hybrid composites for hard tissue replacement. J. Mater. Sci. Technol. 2013, 29, 514-522. [CrossRef]

53. Lee, J.H.; Jang, H.L.; Lee, K.M.; Baek, H.R.; Jin, K.; Hong, K.S.; Noh, J.H.; Lee, H.K. In vitro and in vivo evaluation of the bioactivity of hydroxyapatite-coated polyetheretherketone biocomposites created by cold spray technology. Acta Biomater. 2013, 9, 6177-6187. [CrossRef] [PubMed]

54. Ng, Z.Y.; Nawaz, I. Computer-designed PEEK implants: A peek into the future of cranioplasty? J. Craniofac. Surg. 2014, 25, e55-e58. [CrossRef] [PubMed]

55. Rosenthal, G.; Ng, I.; Moscovici, S.; Lee, K.K.; Lay, T.; Martin, C.; Manley, G.T. Polyetheretherketone implants for the repair of large cranial defects: A 3-center experience. Neurosurgery 2014, 75, 523-529. [CrossRef] [PubMed] 
56. O'Reilly, E.B.; Barnett, S.; Madden, C.; Welch, B.; Mickey, B.; Rozen, S. Computed-tomography modeled polyether ether ketone (PEEK) implants in revision cranioplasty. J. Plast. Reconstr. Aesthet. Surg. 2015, 68, 329-338. [CrossRef] [PubMed]

57. Alonso-Rodriguez, E.; Cebrián, J.L.; Nieto, M.J.; Del Castillo, J.L.; Hernández-Godoy, J.; Burgueno, M. Polyetheretherketone custom-made implants for craniofacial defects: Report of 14 cases and review of the literature. J. Cranio-Maxillofac. Surg. 2015, 43, 1232-1238. [CrossRef] [PubMed]

58. Han, C.-M.; Lee, E.-J.; Kim, H.-E.; Koh, Y.-H.; Kim, K.N.; Ha, Y.; Kuh, S.-U. The electron beam deposition of titanium on polyetheretherketone (PEEK) and the resulting enhanced biological properties. Biomaterials 2010, 31, 3465-3470. [CrossRef] [PubMed]

59. Awaja, F.; Bax, D.V.; Zhang, S.; James, N.; McKenzie, D.R. Cell adhesion to PEEK treated by plasma immersion ion implantation and deposition for active medical implants. Plasma Process. Polym. 2012, 9, 355-362. [CrossRef]

60. Ridwan-Pramana, A.; Wolff, J.; Raziei, A.; Ashton-James, C.E.; Forouzanfar, T. Porous polyethylene implants in facial reconstruction: Outcome and complications. J. Cranio-Maxillofac. Surg. 2015, 43, 1330-1334. [CrossRef] [PubMed]

61. Wang, J.-C.; Wei, L.; Xu, J.; Liu, J.F.; Gui, L. Clinical outcome of cranioplasty with high-density porous polyethylene. J. Craniofac. Surg. 2012, 23, 1404-1406. [CrossRef] [PubMed]

62. Ruszymah, B.H.I.; Chua, K.H.; Mazlyzam, A.L.; Aminuddin, B.S. Formation of tissue engineered composite construct of cartilage and skin using high density polyethylene as inner scaffold in the shape of human helix. Int. J. Pediatr. Otorhinolaryngol. 2011, 75, 805-810. [CrossRef] [PubMed]

63. Oliveira, J.M.; Leonor, I.B.; Reis, R.L. Preparation of bioactive coatings on the surface of bioinert polymers through an innovative auto-catalytic electroless route. In Key Engineering Materials; Trans Tech Publ.: Zurich, Switzerland, 2005.

64. Frederickson, A.M.; Sekula, R.F., Jr. The utility of calcium phosphate cement in cranioplasty following retromastoid craniectomy for cranial neuralgias. Br. J. Neurosurg. 2013, 27, 808-811. [CrossRef] [PubMed]

65. Gilardino, M.S.; Cabiling, D.S.; Bartlett, S.P. Long-term follow-up experience with carbonated calcium phosphate cement (Norian) for cranioplasty in children and adults. Plast. Reconstr. Surg. 2009, 123, $983-994$. [CrossRef] [PubMed]

66. Zins, J.E.; Moreira-Gonzalez, A.; Papay, F.A. Use of calcium-based bone cements in the repair of large, full-thickness cranial defects: A caution. Plast. Reconstr. Surg. 2007, 120, 1332-1342. [CrossRef] [PubMed]

67. Afifi, A.M.; Gordon, C.R.; Pryor, L.S.; Sweeney, W.; Papay, F.A.; Zins, J.E. Calcium phosphate cements in skull reconstruction: A meta-analysis. Plast. Reconstr. Surg. 2010, 126, 1300-1309. [CrossRef] [PubMed]

68. Iwama, T.; Yamada, J.; Imai, S.; Shinoda, J.; Funakoshi, T.; Sakai, N. The use of frozen autogenous bone flaps in delayed cranioplasty revisited. Neurosurgery 2003, 52, 591-596. [CrossRef] [PubMed]

69. Yokoo, S.; Tahara, S.; Sakurai, A.; Hashikawa, K.; Terashi, H.; Furudoi, S.; Umeda, M.; Komori, T. Replantation of an avulsed zygomatic bone as a freeze-preserved autologous graft: A case report. J. Cranio-Maxillofac. Surg. 2003, 31, 115-119. [CrossRef]

70. Morina, A.; Kelmendi, F.; Morina, Q.; Dragusha, S.; Ahmeti, F.; Morina, D.; Gashi, K. Cranioplasty with subcutaneously preserved autologous bone grafts in abdominal wall-Experience with 75 cases in a post-war country Kosova. Surg. Neurol. Int. 2011, 2, 72. [CrossRef] [PubMed]

71. Frazer, R.Q.; Byron, R.T.; Osborne, P.B.; West, K.P. PMMA: An essential material in medicine and dentistry. J. Long-Term Effects Med. Implants 2005, 15, 629-639. [CrossRef]

72. Kriegel, R.J.; Schaller, C.; Clusmann, H. Cranioplasty for large skull defects with PMMA (Polymethylmethacrylate) or Tutoplast processed autogenic bone grafts. Zent. Neurochir. 2007, 68, 182-189. [CrossRef] [PubMed]

73. Becker, L.C.; Bergfeld, W.F.; Belsito, D.V.; Hill, R.A.; Klaassen, C.D.; Liebler, D.C.; Marks, J.G.; Shank, R.C.; Slaga, T.J.; Snyder, P.W.; et al. Final report of the cosmetic ingredient review expert panel safety assessment of polymethyl methacrylate (PMMA), methyl methacrylate crosspolymer, and methyl methacrylate/glycol dimethacrylate crosspolymer. Int. J. Toxicol. 2011, 30, 54S-65S. [CrossRef] [PubMed]

74. Webb, J.; Spencer, R. The role of polymethylmethacrylate bone cement in modern orthopaedic surgery. J. Bone Jt. Surg. Br. Vol. 2007, 89, 851-857. [CrossRef] [PubMed] 
75. Golz, T.; Graham, C.R.; Busch, L.C.; Wulf, J.; Winder, R.J. Temperature elevation during simulated polymethylmethacrylate (PMMA) cranioplasty in a cadaver model. J. Clin. Neurosci. 2010, 17, 617-622. [CrossRef] [PubMed]

76. Togawa, D.; Bauer, T.W.; Lieberman, I.H.; Takikawa, S. Histologic evaluation of human vertebral bodies after vertebral augmentation with polymethyl methacrylate. Spine 2003, 28, 1521-1527. [CrossRef] [PubMed]

77. Pikis, S.; Goldstein, J.; Spektor, S. Potential neurotoxic effects of polymethylmethacrylate during cranioplasty. J. Clin. Neurosci. 2015, 22, 139-143. [CrossRef] [PubMed]

78. Eufinger, H.; Rasche, C.; Wehmöller, M.; Schmieder, K.; Scholz, M.; Weihe, S.; Scherer, P. CAD/CAM titanium implants for cranioplasty-An evaluation of success and quality of life of 169 consecutive implants with regard to size and location. In International Congress Series; Elsevier: Amsterdam, The Netherlands, 2005.

79. Sumner, D. Long-term implant fixation and stress-shielding in total hip replacement. J. Biomech. 2015, 48, 797-800. [CrossRef] [PubMed]

80. Chim, H.; Schantz, J.-T. New frontiers in calvarial reconstruction: Integrating computer-assisted design and tissue engineering in cranioplasty. Plast. Reconstr. Surg. 2005, 116, 1726-1741. [CrossRef] [PubMed]

81. Kurtz, S.M.; Devine, J.N. PEEK biomaterials in trauma, orthopedic, and spinal implants. Biomaterials 2007, 28, 4845-4869. [CrossRef] [PubMed]

82. Scolozzi, P.; Martinez, A.; Jaques, B. Complex orbito-fronto-temporal reconstruction using computer-designed PEEK implant. J. Craniofac. Surg. 2007, 18, 224-228. [CrossRef] [PubMed]

83. Kurtz, S.M. UHMWPE Biomaterials Handbook: Ultra High Molecular Weight Polyethylene in Total Joint Replacement and Medical Devices; Academic Press: Cambridge, MA, USA, 2009.

84. Lin, A.Y.; Kinsella, C.R., Jr.; Rottgers, S.A.; Smith, D.M.; Grunwaldt, L.J.; Cooper, G.M.; Losee, J.E. Custom porous polyethylene implants for large-scale pediatric skull reconstruction: Early outcomes. J. Craniofac. Surg. 2012, 23, 67-70. [CrossRef] [PubMed]

85. Mokal, N.J.; Desai, M.F. Calvarial reconstruction using high-density porous polyethylene cranial hemispheres. Indian J. Plast. Surg. 2011, 44, 422. [PubMed]

86. Couldwell, W.T.; Chen, T.C.; Weiss, M.H.; Fukushima, T.; Dougherty, W. Cranioplasty with the Medpor porous polyethylene flexblock implant: Technical note. J. Neurosurg. 1994, 81, 483-486. [CrossRef] [PubMed]

87. Suwanprateeb, J.; Wasoontararat, K.; Suvannapruk, W.; Leelapatranurak, K.; Wanumkarng, N.; Sintuwong, S. Manufacturing of Porous Polyethylene Ocular Implant by Three Dimensional Printing. KMUTNB Int. J. Appl. Sci. Technol. 2013, 3, 23-28.

88. Karageorgiou, V.; Kaplan, D. Porosity of 3D biomaterial scaffolds and osteogenesis. Biomaterials 2005, 26, 5474-5491. [CrossRef] [PubMed]

89. Abdulai, A.; Iddrissu, M.; Dakurah, T. Cranioplasty using polymethyl methacrylate implant constructed from an alginate impression and wax elimination technique. Ghana Med. J. 2006, 40, 18. [PubMed]

90. Gerber, N.; Stieglitz, L.; Peterhans, M.; Nolte, L.P.; Raabe, A.; Weber, S. Using rapid prototyping molds to create patient specific polymethylmethacrylate implants in cranioplasty. In Proceedings of the 2010 Annual International Conference of the IEEE Engineering in Medicine and Biology Society (EMBC), Buenos Aires, Argentina, 31 August-4 September 2010.

91. Wind, J.J.; Ohaegbulam, C.; Iwamoto, F.M.; Black, P.M.; Park, J.K. Immediate titanium mesh cranioplasty for treatment of postcraniotomy infections. World Neurosurg. 2013, 79, 207.e11-207.e13. [CrossRef] [PubMed]

(C) 2017 by the authors. Licensee MDPI, Basel, Switzerland. This article is an open access article distributed under the terms and conditions of the Creative Commons Attribution (CC BY) license (http:/ / creativecommons.org/licenses/by/4.0/). 